\title{
Technology Transfer Agreement of Multinational Companies in The Framework of Investment Development
}

\author{
Desak Gde Dwi Arini*, Diah Gayatri Sudibya and Ni Made Sukaryati Karma \\ Universitas Warmadewa, Denpasar-Bali, Indonesia \\ desakgdedwiarini@gmail.com
}

Published: 31/08/2021

\begin{abstract}
How to cite:
Arini, D, G, D., Sudibya, D, G., Karma, N, M, S. Technology Transfer Agreement of Multinational Companies in The Framework of Investment Development. Sociological Jurisprudence Journal. Volume 4 Issue 2. Page 86 - 92. https://doi.org/10.22225/scj.4.2.2021.86-92
\end{abstract}

\begin{abstract}
The regulation of technology transfer to Multinational Companies (PMN) to date still pays attention to the provisions of the Law of the Republic of Indonesia No. 25 of 2007 on Investment, especially Article 2 paragraph 1, in addition to Indonesia has also adjusted the provisions of national laws in the field of economy/trade with the provisions of GATT and WTO that hav been ratified through the Law of the Republic of Indonesia Number 7 of 1994, including adjustments to the provisions of the field of intellectual property rights (IPR) contained in the TRIPs, such as the Law of the Republic of Indonesia No. 14 of 2001 on Patents, The Law of the Republic of Indonesia No. 15 of 2001 on Brands, and the Law of the Republic of Indonesia No. 19 of 2002 on Copyright, and others covered as objects of intellectual property rights (IPR). The role of multinational companies (PMN) in the transfer of technology can be mentioned, among others: As a holding company that can be used for media, containers, information exchange, technology between countries in the international community which is further used, and useful for Indonesia; As a place for investment in order to obtain benefits for Indonesia; and As a place for the application of new technologies to be useful more efficiently and effectively benefit Indonesia, in addition to improving international economic trade.
\end{abstract}

Keywords: agreement; investment; multi national company; transfer technology

\section{INTRODUCTION}

Our economic life today is characterized by rapid capital traffic, both foreign capital and domestic capital. All of them stormed into the center of our economy freely and lawfully. Juridically, they are protected, because they support the economic development program that is being implemented. The government itself feels unprepared to build and therefore foreign capital is invited through the Law of the Republic of Indonesia on Investment, namely the Law of the Republic of Indonesia Number 25 of 2007.

Over the past twenty years, the Law of the Republic of Indonesia on Investment has succeeded in incorporating foreign capital into Indonesia, both in terms of capital and in terms of projects. Almost all foreign capital entering Indonesia is the capital of multinational companies (PMN) or multinational corporations (MNC). Multinational companies entering Indonesia are not independent, but they are in a relationship of the international economic system with an organized organization, neat. An international economic syndicate with the support of cutting-edge technology. The relationship between countries and all their affiliates place foreign investors in Indonesia in the chain of international economic activities that are very large and monopolized. In the end, the activities of multinational companies can be powerful so as to create dependencies, not only over technology but 
also on low-tech goods that can be produced, in this case, we see unfair competition (unhealthy competition) in multinational companies that turn off small entrepreneurs that generally consist of national entrepreneurs.

For developing countries (in this case including Indonesia), improving their development does not have to find technology individually, but more efficient when carrying out technology transfer from foreign investors from developed countries, without forgetting the effort to find it yourself.

Developed countries are constantly discovering new processes and machines that are more

complicated and more economical. While developing countries are still at the level of trying with all efforts to reduce the distance of technological backwardness with developed countries. (Rosyidah Rakhmawati, 2003:79)

Industries in developing countries have no choice but to follow carefully a technological advancement for industrial production to compete with imported goods produced by developed countries, both from quality and price, without the industry is protected by the imposition of high import duty tariffs.

Multinational companies (PMN) engaged around the world have a philosophy that is for prosperity that is run in the form of profits obtained by the company. This is supported by the company's capital, technology, knowledge, and management through the skills of its managers. In line with that, every country that opens the operational opportunities of multinational companies (PMN) also expects benefits that are beneficial for the development of the nation, where one of the benefits is the transfer of technology (transfer of technology). Although multinational companies (PMN) is not a single role in the transfer of technology but have a fairly important portion in the development of technology from the receiving country of capital. However, in the course of multinational companies (PMN) often arise problems stemming from the gap between the origin of capital and the receiving country of capital. However, in the course of multinational companies (PMN) often arise problems stemming from the gap between the origin of capital and the receiving country of capital, both in the political, legal, economic, and social fields. On the one hand, this is felt unnatural, considering the various facilities provided by the government as a political willingness to multinational companies (PMN) less compensated with donations made to the receiving country of capital.

Indonesia until now has not had its laws regarding technology transfer agreements. Therefore, technology transfer agreements must be subject to the applicable treaty law. The general provisions of the agreement stipulated in book III of the Civil Code (titleS I to title IV) apply also to agreements relating to technology transfer. This is based on the provisions of Article 1319 of the Civil Code, which stipulates that all agreements either having a specific name or not being known by a particular name, are subject to general regulations.

The provisions of the Civil Code follow the principle of freedom of contract as stated in

Article 1338 paragraph (1). With the principle of freedom of contract, then any legal subject can enter into any agreement as long as the agreement meets the requirements of the validity of an agreement listed in Article 1320 of the Civil Code. Thus the principle of freedom of contract prohibits interference from the state/government to the agreement made by the parties. Based on this, the agreements on the transfer of technology should not be intervened by the state/government. This of course resulted in the government not being able to control every content of the agreements regarding the transfer of technology. The government will not know, that there has been a transfer of technology or just the mobility of technology, whether it is

promised to be diverted, whether the technology obtained is relevant for national development because the government can not or is impossible to control any agreement over the technology.

Starting from the background above, there are some problems concerning the title of this journal. The problem can be formulated as follows: how is the regulation of technology transfer agreements against Multinational Companies (PMN)?, and how is the role of Multinational Companies $(\mathrm{PMN})$ on technology transfer to increase the development of investment?

\section{METHODS}


The research used is normative law research that is by reviewing the prevailing laws and regulations in positive law. (Sunaryati Hartono, 1994: 131-141) The problem approach used in this study is to use a conceptual approach and a statutory approach which means that here the author sees the rules of law that apply especially to the technology transfer agreements of multinational companies in the framework of investment development. After the legal materials are collected, the legal materials are processed and analyzed using qualitative methods. After going through the process of processing and analysis, then the legal material is presented descriptively analysis. Descriptive means the expo of research results systematically and thoroughly concerning facts related to research problems. While the analysis means that the facts related to the research are analyzed carefully so that then the conclusions of the research results are obtained.

\section{III.RESULTS AND DISCUSSION}

\section{Regulation of Technology Transfer Agreements against Multinational Companies (PMN)}

The Constitution of the Republic of Indonesia year 1945 mandated that national goals among others to advance the general welfare and educate the life of the nation. Also, it is also asserted that the earth, and the water and natural wealth contained therein are controlled by the state and used as much as possible for the prosperity of the people. Therefore, efforts to benefit, develop, and master science and technology are directed to continuously improve the intelligence of the human nation, increase the value of goods and services, and the welfare of the community through the acceleration of industrialization as part of sustainable development by heeding environmental conditions and social conditions of society.

Multinational Company Activities (PMN) create part of economic activities. The relationship of PMN activities with the capital receiving country is carried out in a series of legal foundations in the form of laws and regulations. The impact of PMN's economic activities on the social and political aspects of the capital receiving country is a matter of consideration for the discretion of the government of the country, following its sovereignty. In this case, the entry and permitting of PMN to conduct activities in the capital receiving country, in turn, demands integrated feasibility with all aspects to achieve the expected mutualistic benefits.

The application of the political foundation of PMN in other countries in the world, concerned with a series of political requirements, among others, how far pmn operational activities are in line with the politics of national development and international relations of the receiving country of capital. These include monetary fiscal policy, organizing trade with healthy competition, preventing monopolies and oligopoly, protecting domestic industries, and developing weak economic groups.

Indonesia as well as most other countries in the world in inviting PMN to conduct activities in the country is based on consideration of the foundation of ideology and politics of the country. Furthermore, it is stated in the Law of the Republic of Indonesia Number 25 of 2007 which determines; a mutual understanding between the PMN and the government of the capital receiving country that foreign capital of PMN is a complementary additional source in national development financing and does not cause dependence on foreign sources; For the implementation of development there needs to be a set of laws and regulations that become the basis of the operational activities of the PMN; To achieve the development goals, the government of the capital receiving country seeks to increase national business and improve the national economic capability in general; Based on the above considerations, it is necessary to find alternatives to the role of PMN and at the same time expand potential sources for development. Based on the provisions of Article 1 of the Law of the Republic of Indonesia Number 25 of 2007, that foreign investment includes foreign direct investment. In the sense that the owner of the capital directly bears the risk of such foreign investment.

If we look at the understanding of investment directly, it turns out that investors are given the flexibility to try and organize leaders in companies where the capital is invested, in the sense that investors have control over capital. While we know that investors who have power over the capital they invest is only owned by multinational companies. So that based on the provisions of Article 1 of the Law of the Republic of Indonesia Number 25 of 2007 on Investment, determines that there is an 
opportunity for multinational companies to develop their businesses in Indonesia. Foreign capital that can be planted in Indonesia, in addition to money, can also be in the form of technology under the provisions of Article 2, which specifies that the tools obtained not on the cost/burden of Indonesia's foreign exchange wealth, meaning that the tools are not purchased using a foreign exchange that is in the control of the state.

Seeing the wisdom of Government Regulation of the Republic of Indonesia Number 20 of 1994, this is as the discretion of the Republic of Indonesia in anticipating the impact of GATT provisions that have been ratified by Indonesia. Similarly, the ratification of the establishment of the World Trade Organization (WTO) by Indonesia and the Law of the Republic of Indonesia No. 7 of 1994. And the WTO is effective since January 1, 1995, so that with the approval of the WTO by Indonesia signifies the beginning of efforts to realize a free, fair, and open trade system. Because with the WTO, the agreement produced in the Uruguay Round (GATT) will be able to be implemented effectively. Thus open international market opportunities, as a result of commitment in the field of trade in goods and services, and in this case, will benefit Indonesia for it must be ready to compete with foreign investors who already have advanced technology.

As a MEMBER state of the WTO, Indonesia has taken several strategic steps in fulfilling its obligations as determined by TRIPS (Agreement On Trade-Related Aspects Of Intellectual Property Rights) which is one part of the WTO agreements has triggered phenomenal changes to the development of intellectual property protection systems (IPR) around the world, including Indonesia the existence of this intellectual property rights, which have the following objects: Copyrights and related rights; Brand; Geographical indications; Industrial design; Patents; Integrated circuit layout design; and protection of trade secrets, very closely with the transfer technology that can bring benefits in the form of benefits for the country of Indonesia. (Capacity Building, 2004: 10)

Therefore, through intellectual property rights (IPR) there can also be a transfer of technology that can bring benefits to Indonesia's national development. New laws and regulations in the field of IPR in Indonesia include Law of the Republic of Indonesia Number 30 of 2000 concerning Trade Secrets; Law of the Republic of Indonesia Number 31 of 2000 concerning Industrial Design; Law of the Republic of Indonesia Number 32 of 2000 concerning Integrated Circuit Layout Design; Law of the Republic of Indonesia Number 14 of 2001 concerning Patents; Law of the Republic of Indonesia Number 15 of 2001 concerning Brands, and; Law of the Republic of Indonesia Number 19 of 2002 concerning Copyright. (Compilation of Law RI, Director General of IPR, 2004: 1-235). Furthermore, the policy of the Government of the Republic of Indonesia on the Long-Term Development Plan (RPJPN), that the priority of sector development in the economic sector with the connection between industry and agriculture and other development fields an improve the quality of human resources. The organization and establishment of national industries lead to the strengthening, experience, improvement, expansion, and dissemination of industry throughout Indonesia. While in the field of improving the ability to utilize science and technology is implemented by prioritizing the improvement of technology transfer capabilities supported by the development of human resources capabilities, facilities, and infrastructure of education quality research to support efforts to strengthen the experience, and expansion of industry to support the industrialization process towards the realization of an advanced, independent, and prosperous Indonesian nation.

The presence of multinational companies with advanced technology has opened new horizons of legal thinking of the Indonesian government such as by noting the issue of protection of intellectual property rights (IPR) both in the field of patents, from the production of finished goods produced by domestic companies and foreign companies located in Indonesia as well as intellectual property rights in other fields such as copyright. Moreover, with the provisions of GATT as a result of the agreement in Marrakesh and the establishment of the World Trade Organization (WTO) which has been ratified by Indonesia through the Law of the Republic of Indonesia No. 7 of 1994 and balanced with the Government of the Republic of Indonesia Regulation No. 20 of 1994 concerning the policy of the Government of Indonesia in anticipating the impact of GATT and WTO provisions that have been ratified by Indonesia. The ratification of the WTO by Indonesia signifies the beginning of efforts to realize a free, fair, and open trade system. Because with the WTO, the agreement produced in Uruguayan regulations (GATT) will be implemented effectively, so that international market 
opportunities will be open, as a result of commitments in the field of trade and services. This can benefit Indonesia to boost its export activities, although for that it must be ready to compete with foreign investors who already have advanced technology.

Considering the legal regulation in the field of international trade owned by Indonesia, by having also ratified the provisions of GATT / WTO, in addition to Indonesia that as per the provisions in the national law. Especially in the field of economic law, including in the field of intellectual property rights (IPR), it can be said that multinational companies (PMN) located in Indonesia in the transfer of technology/transfer of technology will get legal protection, both internationally and nationally, namely Indonesian national law.

\section{The Role of Mulitinasional Company (PMN) on Technology Transfer in Investment Development}

Understanding the mastery of advanced industrial technology for most developing countries, especially those just entering the early stages of industrial processes is a difficult and expensive process. So it is often easier for developing countries to acquire advanced technology through the process of transfer of technology of multinational companies that are usually from the parent company to the branch of a multinational company in the host country. With the acceptance of such technology, the branch of this multinational company can run the production process more efficient and increase productivity and revenue factors employed in the branch of the company concerned, including local production factors. The transfer of technology from multinational companies can not only occur through intra multinational companies but also by the form of pure licensing contracts between multinational companies and national companies in developing countries that do not have foreign capital participation. This license covers all forms of industrial property rights, such as patents and trademarks, know-know licenses such as plans, details, specifications, service and training contracts, engineering designs, plant installations, and equipment acquisition forms, equipment, semi-finished goods, and raw materials, as long as these acquisitions are part of the transfer of technology transactions., and approval of industrial and engineering cooperation, such as international subcontracting, turnkey arrangements, and procurement of management and marketing services. Phases of technology transfer according to Melvin Kranzberg, there are three phases of technology transfer, namely: (Syamsudin Ukardi: 1978: 20)

Material transfer, in this phase, happens is only the transfer or import of machines, equipment, materials, and technical data related to the machine and the materials related to the machine and the materials. Here there is no transfer of technology as a science, but rather a transfer of industrial results or technological results; Design Transfer, in this phase the transfer of technology occurs mainly through design elements, such as blueprints, design formulas, and so on. Machinery equipment and materials from abroad are imported to make the goods according to the design. Capacity Transfer, in this phase the transfer of technology occurs through the transfer of knowledge and knowledge as well as specialized expertise in the technical field. Even in some countries, it happens because of the displacement of scholars and experts. The transfer of technology in this phase, not only creates the ability to produce goods according to the design or formula obtained, but creates the ability to develop the product, even the ability to diversify in production. The transfer of technology in this phase is more focused on the transfer of knowledge and expertise than the transfer of machines, equipment, and materials or design so that the recipient can develop his abilities.

When associated between these phases, the transfer of technology by multinational companies always does so from the first stage or phase of the transfer of the machines needed to produce in the country in which it operates. The transfer of technology through the importation of these machines is carried out by most companies engaged in the production of finished goods, then the phase carried out is the second phase of technology transfer in the field of design and formula. But this is simply a purchase of a license or patent from a company that has created and owned it. In Indonesia, today with the era of globalization in the field of the economy with the ratification of GATT and WTO means That Indonesia is ready to compete in the field of technology with other countries. In this regard, it is now a challenge for Indonesia to adapt to the technology owned by developed countries. Because however, Indonesia in the field of the economy has entered the international market by referring to the provisions of GATT, especially GATT principles must be applied such as national treatment, as well 
as foster competitive advantage economic competition, or an honest and fair economy in competition.

In addition to the attitude of governments of developing countries that positively encourage the growth of their own multinational companies and investment activities abroad, there are still two other factors that support these investment activities, namely: Solidarity among third world countries, this factor in some ways may have played an important role in the efforts of some developing countries to attract foreign investors from other developing countries; The availability of more appropriate technology, this factor also has an important role in attracting direct investment from developing countries. For developing countries that face many labor advantages, the appropriate technology for a labor-intensive environment used by multinational companies from developing countries is an important consideration factor in the effort to attract investors from abroad. (The Kian Wie, 1982: 67) When viewed the patterns of foreign investment activities by multinational companies from developing countries, it will be revealed that the countries of origin of the company can be distinguished into 3 (three) categories, namely:

Developing countries rich in natural resources, especially OPEC countries, generally want to implement a rapid international expansion program stimulated by abundant income from the export of their natural resources. Such income allows developing countries to exercise managerial and technological skills to carry out international expansion programs, primarily through state companies; Developing countries that are rich in labor and are undergoing a rapid industrialization process, such as Taiwan, South Korea, Hongkong, and Singapore have only limited natural resources and relatively small domestic markets. Therefore these countries were forced to turn to overseas markets to sell produce from their industries; Developing countries with a wide domestic market and are undergoing a rapid industrialization process. (Ibid.) As seen in Indonesia today, this has changed since ratified gatt and WT ovisions, the same is no longer differentiating production, but there is competition for products in the national market and international markets under the content and principles of GATT as the approval of Marrakesh.

Judging by the position of the Indonesian state today, which is already in a competitive condition of globalization, multinational companies in the transfer of technology in Indonesia can be said to have the following roles; As a holding company that can be used for media, containers, technology information exchange, between countries in the international community, which is further useful and useful for Indonesia; As a place for investors to obtain benefits for the national country; as a place for the application of new technologies to be useful more efficiently and effectively profitable nationally; and As a medium for the improvement of international economic trade.

\section{IV.CONCLUSION}

From the results of the discussion above, it can be concluded as follows: The regulation of technology transfer to Multinational Companies (PMN) to date still pays attention to the provisions of the Law of the Republic of Indonesia No. 25 of 2007 on Investment, especially Article 2 paragraph 1, in addition to Indonesia has also adjusted the provisions of national laws in the field of economy/trade with the provisions of GATT and WTO that have been ratified through the Law of the Republic of Indonesia Number 7 of 1994, including adjustments to the provisions of the field of intellectual property rights (IPR) contained in the TRIPs, such as the Law of the Republic of Indonesia No. 14 of 2001 on Patents, The Law of the Republic of Indonesia No. 15 of 2001 on Brands, and the Law of the Republic of Indonesia No. 19 of 2002 on Copyright, and others covered as objects of intellectual property rights (IPR).

The role of multinational companies (PMN) in the transfer of technology can be mentioned, among others: As a holding company that can be used for media, containers, information exchange, technology between countries in the international community which is further used, and useful for Indonesia; As a place for investment to obtain benefits for Indonesia; and As a place for the application of new technologies to be useful more efficiently and effectively benefit Indonesia, in addition to improving international economic trade. 


\section{References}

Capacity Building, (2004), Program on the Implementation of the WTO Agreement in Indonesia (TRIPS Component), Training Material on Enforcement of Intellectual Property Rights), Developed by Japan International Cooperation Agency, JICA WTO Consultan Team in

Cooperation with Directorate General of Intellectual Property Rights Minista ustice and Human Right Republic of Indonesia, JICA.

Hartono, S. (1994). Penelitian Hukum di Indonesia pada Akhir Abad ke-20, Bandung: Alumni

Kartono, K. (1995). Metode Pembuatan Kertas Kerja atau Skripsi Ilmu Hukum. Dalam Hilman Adikusuma, Bandung: Mandar Maju

Kompilasi Undang-undang RI di Bidang Hak Kebudayaan Intelektual (Jakarta oleh Dirjen Hak Kekayaan Intelektual, (2004), Departemen-Kehakiman dan HAM RI, Kerjasama dengan Japan International CoOperation Agency, (JICA).

Peraturan pemerintah Republik Indonesia Nomor 20 tahun 1994 tentang kebijakan pemerintah RI dalam mengantisipasi dampak dari ketentuan GATT dan WTO yang sudah diratifikasi oleh Indonesia

Rakhmawati, R.(2003). Hukum Penanaman Modal di Indonesia dalam Menghadapi Era Global, Cetakan Pertama, Jakarta: Bayu Media Publishing

The Kian Wie, (1982), Perusahaan Multinasional dari Negara Berkembang di Indonesia, Artikel dalam Majalah Management \& Usahawan Indonesia, Edisi Maret-April.

Ukardi, M, S. (1981). Permasalahan pada Pengalihan Teknologi dalam Bidang Industri, yang disampaikan dalam seminar Aspek-aspek Hukum dari Hukum Nasional Departemen Kehakiman Bekerjasama dengan Universitas Samratulangi Manado, Binacipta, Bandung.

Ukardi, S. (1978). Permasalahan pada Teknologi Dalam Bidang Industri, Kertas Kerja pada Seminar Aspekaspek Hukum dari Pengalihan Teknologi, Manado.

Undang-Undang Republik Indonesia Nomor 25 Tahun 2007 tentang Penanaman Modal. Undang-Undang Republik Indonesia Nomor 14 Tahun 2001 tentang Paten.

Undang-Undang Republik Indonesia Nomor 11 Tahun 2008 tentang Informasi dan Transaksi Elektronik

Undang-Undang Republik Indonesia Nomor 40 Tahun 2007 tentang Perseroan Terbatas (PT). 